Dhaka Univ. J. Biol. Sci. 29(2): 137-145, 2020 (July)

\title{
GROWTH PERFORMANCES AND PROXIMATE COMPOSITION OF MYSTUS CAVASIUS (HAMILTON, 1822) CULTURED IN RECIRCULATING AQUACULTURE SYSTEM UNDER DIFFERENT STOCKING DENSITIES
}

\author{
Md. Mizanur Rahman, Gouri MondaL*, Md. Marufujjaman Mithu, \\ Md. Golam Rabbane and Md. Ghulam Mustafa \\ Department of Fisheries, University of Dhaka, Dhaka-1000, Bangladesh
}

Key words: Mystus cavasius, Stocking density, Growth performance, Survival rate

\begin{abstract}
Experiment was conducted to evaluate the high density culture of Mystus cavasius and its effects on growth performances, survival rate and proximate composition of the fish in recirculating aquaculture system. Fishes were cultured at 571, 714, 857 and 1000 fries $/ \mathrm{m}^{3}$ as the initial stocking density. No significant differences $(\mathrm{p}>0.05$ ) were found in specific growth rate, average daily gain, food conversation ratio, protein efficiency ratio, condition factor $(\mathrm{k})$ and survival rate (\%) of fish under the culture period of 120 days among the different stocking densities. The average survival rate was $\geq 99 \%$ among the treatments at the end of the culture period. The moisture contents were between 77.10 and $77.75 \%$, ash content was 2.58 and $2.61 \%$, crude protein was 15.86 and $16.07 \%$, crude lipid was 5.45 and $5.68 \%$ with no significant differences ( $p>0.05)$ among the treatments. There were no significant variations in DO, TAN, NO$-\mathrm{N}, \mathrm{NO}_{2}-\mathrm{N}$ and $\mathrm{pH}$ among the treatments during culture. This study showed that stocking density of at least 1000 fries $/ \mathrm{m}^{3}$ was the best option as the total gain was highest compared to other lower densities under similar facilities.
\end{abstract}

\section{Introduction}

Mystus cavasius (Hamilton, 1822) is one of the important silurid catfish of Bagridae family locally known as 'Gulsha tengra'(1). It was abundant in rivers, oxbow lakes, floodplains, swamps and canals in Bangladesh, India, Myanmar, Sri Lanka, Nepal and Pakistan(2). Though it can survive in poor environmental conditions such as low oxygen, extensive temperature fluctuations and acute water conditions, the natural habitats and breeding grounds of this silurid catfish have been severely destroyed in recent years as a result of environmental agitation and man-induced hazards in the aquatic ecosystems ${ }^{(3)}$. Still for its delicious taste and rich nutrient value, the fish is a favourite fish to the consumers. Besides it has high demand which offers high price in the market.

*Author for correspondence: <gourimondal2016@gmail.com>. 
Development of a suitable technology for rearing of this fish is very essential to increase production as well as its conservation and rehabilitation. To increase the production of this fish, high level stocking density is needed in a small area. It would be necessary to stock at suitable stocking density for optimum growth, survival and to get maximum production as well as profit of this fish ${ }^{(4,5)}$. In this case recirculating aquaculture system (RAS) can be used to culture Mystus cavasius at high stocking density in indoor tanks with a controlled environment. RAS can be used as grow out system to produce food fish or as hatchery to produce eggs and fingerlings of fish for stocking and ornamental fish for home aquarium ${ }^{(6)}$. It needs a very small area and allows the grower to protect the fish form disease and produce high yields per unit area ${ }^{(7)}$. RAS is alternative to outdoor open aquaculture where water is continuously recycled and observed to keep a suitable culture environment for fish round the year(8).

From previous studies it appears that no study has yet been undertaken on stocking density of Mystus cavasius for culturing in RAS in Bangladesh ${ }^{(9,10)}$. Researchers studied the effects of density on growth and survival rate of Mystus cavasius in ponds ${ }^{(9,10)}$. But no information is available on the effects of different stocking densities on growth and survival rate of the catfish Mystus cavasius in RAS. Hence, the present study was undertaken to estimate the growth performance and proximate compositions of Mystus cavasius under different stocking densities cultured for 120 days in RAS.

\section{Materials and Methods}

Fries of gulsha (Mystus cavasius) were collected from Annopurna Agro Hatchery at Trishal Upazila in Mymensingh district. Fries were transported with oxygenated polythene bags. The fries used in the experiment were $1.41 \pm 1.37 \mathrm{~cm}$ in length and $0.36 \pm$ $0.82 \mathrm{~g}$ in weight (mean \pm SEM).

The growth performance of Mystus cavasius was conducted in recirculating aquaculture system (RAS) fish farm located at Bhararia, Bolora, Manikgonj. Proximate analysis of fish muscle was done in the laboratory of Department of Fisheries, University of Dhaka. Twelve circular tanks were installed in RAS farm having 7000 liters $\left(7 \mathrm{~m}^{3}\right)$ water holding capacity of each. A bio-filter and a mechanical filter were installed as per designed tanks.

Initially, four different stocking densities including 571, 700, 857 and $1000 \mathrm{fries} / \mathrm{m}^{3}$ were set. The fries were released into four different treatments (T1, T2, T3 and T4). There were three replicates each of the four stocking densities.

On the first day, no feed was given. From the second day of stocking, commercial floating feed with size $0.5 \mathrm{~mm}$ was given at $10 \%$ of body weight of the fish for first 14 days. The next 90 days fishes were fed at $8 \%$ of body weight and final 15 days fish were fed at $6 \%$ of body weight. After first 15 days of the culture period feed with size $1.2 \mathrm{~mm}$ were given. Fish were fed twice daily with automatic feeder in all treatment tanks. 
To evaluate the growth performance of fish, condition factor $(k)$, average daily gain (ADG), feed conversion ratio (FCR), protein efficiency ratio (PER), specific growth was measured with measuring scale and weight with weighing balance. Experiment continued up to 120 days.

Moisture, ash, crude protein and crude lipid content were determined by the method of $\mathrm{AOAC}^{(12)}$.

Water quality parameters were kept within the range of optimum conditions to ensure the survival of both the cultured fish species and the nitrifying bacteria inhabiting at the biofilter within the RAS especially when fish were stocked at high densities. DO and $\mathrm{pH}$ levels were observed using $\mathrm{DO}$ and $\mathrm{pH}$ meter. Then $\mathrm{TAN}, \mathrm{NO}_{3}-\mathrm{N}$ and $\mathrm{NO}_{2}-\mathrm{N}$ were determined via Hach colorimetric assays using a D $\mathbb{R} 2500$ spectrophotometer. Biofilter maintained the growth of microbial community as it was helpful for eliminating the nitrogenous wastage.

The data were analyzed through ANOVA using SPSS (ver. 20) followed by Tukey HSD. The level of significance was set at $5 \%(p>0.05)$.

\section{Results and Discussion}

Different parameters of Mystus cavasius were observed for 120 days (Table 1). The statistical analysis showed that the value of specific growth rate (SGR) of $M$. cavasius cultured in RAS were not significantly different $(p>0.05)$ among four treatments whereas the lowest and highest SGR were found in T4 $(0.40 \pm 0.024 \%)$ and in T3(0.44 \pm $0.035 \%)$, respectively (Table. 1$)$. The values of SGR of T1 and T2 were $(0.44 \pm 0.027 \%)$ and $(0.43 \pm 0.025 \%)$, respectively. Moreover the highest average daily gain (ADG) was obtained in T3 $(0.21 \pm 0.011 \mathrm{~g} /$ day $)$ and the lowest was recorded inT4 $(0.17 \pm 0.021 \mathrm{~g} /$ day $)$ (Table1). But there was no significant difference $(\mathrm{p}>0.05)$ among the treatments.

Table 1. Growth performance (Mean \pm SEM) for 120 days. ${ }^{a}$

\begin{tabular}{cllllll}
\hline $\begin{array}{l}\text { Treat- } \\
\text { ment }\end{array}$ & $\begin{array}{l}\text { Specific } \\
\text { growth rate } \\
(\%)\end{array}$ & $\begin{array}{l}\text { Feed } \\
\text { conversion } \\
\text { ratio }\end{array}$ & $\begin{array}{l}\text { Condition } \\
\text { factor }(\%)\end{array}$ & $\begin{array}{l}\text { Survival rate } \\
(\%)\end{array}$ & $\begin{array}{l}\text { Protein } \\
\text { efficiency } \\
\text { ratio }\end{array}$ & $\begin{array}{l}\text { Feed conver- } \\
\text { sion efficiency } \\
(\%)\end{array}$ \\
T1 & $0.44 \pm 0.027^{\mathrm{a}}$ & $1.44 \pm 0.143^{\mathrm{a}}$ & $0.88 \pm 0.022^{\mathrm{a}}$ & $99.28 \pm 0.172^{\mathrm{a}}$ & $1.65 \pm 0.111^{\mathrm{a}}$ & $76.13 \pm 5.139^{\mathrm{a}}$ \\
$\mathrm{T} 2$ & $0.43 \pm 0.025^{\mathrm{a}}$ & $1.40 \pm 0.104^{\mathrm{a}}$ & $0.84 \pm 0.028^{\mathrm{a}}$ & $99.25 \pm 0.069^{\mathrm{a}}$ & $1.64 \pm 0.092^{\mathrm{a}}$ & $75.88 \pm 4.245^{\mathrm{a}}$ \\
$\mathrm{T} 3$ & $0.44 \pm 0.035^{\mathrm{a}}$ & $1.45 \pm 0.125^{\mathrm{a}}$ & $0.82 \pm 0.027^{\mathrm{a}}$ & $99.38 \pm 0.062^{\mathrm{a}}$ & $1.62 \pm 0.111^{\mathrm{a}}$ & $74.97 \pm 5.116^{\mathrm{a}}$ \\
$\mathrm{T} 4$ & $0.40 \pm 0.024^{\mathrm{a}}$ & $1.47 \pm 0.093^{\mathrm{a}}$ & $0.82 \pm 0.026^{\mathrm{a}}$ & $99.04 \pm 0.022^{\mathrm{a}}$ & $1.55 \pm 0.092^{\mathrm{a}}$ & $71.52 \pm 4.270^{\mathrm{a}}$ \\
\hline
\end{tabular}

${ }^{a}$ No significant differences were detected $(\mathrm{p}>0.05)$ among treatments under same superscript letter reared for 120 days.

Highest condition factor $(\mathrm{k})$ value was recorded in $\mathrm{T} 1(0.88 \pm 0.022)$ and lowest was obtained in T4 $(0.81 \pm 0.032)$. The $\mathrm{k}$ values of RAS cultured $M$. cavasius were not significantly varied $(p>0.05)$ among the treatments (Table 1 ). 
Highest protein efficiency ratio (PER) was found in T1 (1.65 \pm 0.111$)$ and lowest was recorded in T4 $(1.55 \pm 0.092)$. There was no significant difference $(p>0.05)$ among the treatments (Table. 1). Whereas the lowest Feed Conversion Ratio (FCR) was obtained in T2 $(1.40 \pm 0.104)$ and highest in T4 $(1.47 \pm 0.093)$ in RAS.

The mean SGR was $\geq 1.54 \%$ for total culture duration (120 days) among all treatments whereas average SGR value was $1.14 \%$ for $M$. cavasius in pond aquaculture ${ }^{(13)}$. This result showed that the SGR value in RAS was better than pond aquaculture(10).

In RAS the FCR values (1.18 - 1.47) of Mystu scavasiu was not significantly different among four treatments. Besides it was near to the FCR value (1.37) of pond aquaculture(9). The values of FCR rely on numerous factors shown ever the best result can be found if the culture environment is suitable for fish ${ }^{(14)}$. Here culture environment was optimized by treating water ${ }^{(15)}$.

For this study period of 120 days there was no significant difference $(p>0.05)$ in PER among different treatments. Pond culture showed that PER value of Mystus cat fish was between 1.46 and $1.62^{(16)}$. Here the PER value ranged from 1.55 to 1.84 which indicated RAS system performed better than typical pond aquaculture.

When initial stocking density was 1000 fries $/ \mathrm{m}^{3}$ lowest survival rate of $M$. cavasius was recorded in T4 $(99.04 \pm 0.022 \%)$ and highest was recorded in T3 $(99.38 \pm 0.062 \%)$. But there was no significant difference $(p>0.05)$ in survival rate among four densities (Table 1). Furthermore one study in pond aquaculture showed that the survival rate of Mystus cavasius ranged from $(51.67-65.67 \%)^{(9)}$. That result indicated that the mean survival rate was $\geq 99 \%$ at the end of 120 days which was better than pond aquaculture.

There were no significant differences ( $\mathrm{p}>0.05)$ in moisture $(\%)$, ash $(\%)$, crude protein (\%) and crude lipid (\%) of Mystus cavasius cultured for a period of 120 days in RAS (Table 2). Dresosier ${ }^{(17)}$ showed that moisture content of fish fluctuated from $70-80 \%$ which depends on seasons, sex, age etc. In this experiment the moisture content ranged from 77.10 to $78.19 \%$ almost similar to the ranges of Stansby ${ }^{(18)}$. In case of the ash content $4.77 \%$ was found from indigenous M. cavasius in an earlier study of Dresosier ${ }^{(17)}$. Though the ash content from this RAS cultured fish ranged from 2.58 to $2.61 \%$ which was slightly lower than that result. Moreover, Ahmed et al.(19) showed that the ash content of this species from paddy field was $1.27 \%$. Thus the value of ash content varies with changing culture conditions. Crude protein and crude lipid content were found to be15.86 - 16.07\% and $5.45-5.68 \%$, respectively from RAS cultured M. cavasius. Research workers found crude protein content $16.8 \%$ and crude lipid content $5.1 \%$ from the captured $M$. cavasius in Bangladesh ${ }^{(20)}$. In another study Protein level of indigenous $M$. cavasius was $16.1 \%^{(17)}$. In both cases of protein and lipid, results were almost similar to the previous studies.

In this experiment (Table 3), the DO level was maintained (15.33 - $16.20 \mathrm{mg} /$ ) among the treatments because of higher stocking density of the species. According to Pillay et al.(20)for optimum growth of fishes require a minimum $\mathrm{DO}$ concentration of 
approximately $5.0 \mathrm{mg} \Lambda$ (warm water species) to $7.0 \mathrm{mg} \Lambda$ (cold water species) depending upon species. Whereas in RAS the minimum DO concentration was safe for fish is dependent on the concentration of dissolved $\mathrm{CO}_{2}$ present in the water ${ }^{(22)}$. Even the 20 $\mathrm{mg} /$ of DO concentration, recommended as safe for fish culture, is at or above saturation level $(22,23)$.

Table 2. Proximate composition (Mean \pm SEM) of gulsha (M. cavasius) cultured in RAS.a

\begin{tabular}{lcccc}
\hline Treatment & $\begin{array}{c}\text { Moisture } \\
(\%)\end{array}$ & $\begin{array}{c}\text { Ash } \\
(\%)\end{array}$ & $\begin{array}{c}\text { Lipid } \\
(\%)\end{array}$ & $\begin{array}{c}\text { Protein } \\
(\%)\end{array}$ \\
\hline T1 & $77.58 \pm 0.153^{\mathrm{a}}$ & $2.61 \pm 0.054^{\mathrm{a}}$ & $5.68 \pm 0.058^{\mathrm{a}}$ & $15.98 \pm 0.112^{\mathrm{a}}$ \\
$\mathrm{T} 2$ & $77.75 \pm 0.145^{\mathrm{a}}$ & $2.59 \pm 0.058^{\mathrm{a}}$ & $5.49 \pm 0.048^{\mathrm{a}}$ & $16.07 \pm 0.101^{\mathrm{a}}$ \\
$\mathrm{T} 3$ & $77.10 \pm 0.254^{\mathrm{a}}$ & $2.58 \pm 0.032^{\mathrm{a}}$ & $5.47 \pm 0.060^{\mathrm{a}}$ & $15.86 \pm 0.116^{\mathrm{a}}$ \\
T4 & $78.19 \pm 0.171^{\mathrm{a}}$ & $2.60 \pm 0.043^{\mathrm{a}}$ & $5.45 \pm 0.040^{\mathrm{a}}$ & $15.93 \pm 0.131^{\mathrm{a}}$ \\
\hline
\end{tabular}

${ }^{a}$ No significant differences were identified (p 0.05) among treatments under same alphabet reared for 120 days.

Fivelstad et al. ${ }^{(24)}$ suggested that a maximum limit of $\mathrm{CO}_{2}$ may be as low as $10 \mathrm{mg} /$ for safety aspects. For these reasons, DO is usually the first water quality parameter to limit culture tank carrying capacity. This study detected no significant difference $(p>0.05)$ among the treatments. Previous study reported that the NO3-N level concentration levels should be lower than $10 \mathrm{mg} A$ in $\mathrm{RAS}^{(21)}$. In this experiment nitrate $\left(\mathrm{NO}_{3}-\mathrm{N}\right)$ level was $(0.34$ - 0.37) $\mathrm{mg} /$ and $\mathrm{NO}_{2}-\mathrm{N}$ was $(0.32$ - 0.34) $\mathrm{mg} /$ among the treatments and there were no significant differences among the treatments (Table 3). Besides $\mathrm{pH}$ level was between 7.0 and 7.1 which was almost neutral (Table 3).

According to previous study, TAN level should be maintained below $0.5 \mathrm{mg} \lambda$ for catfish culture in RAS as a general rule as lethal level of TAN for catfish is $3.10 \mathrm{mg} \lambda^{(23)}$. When $1.0 \mathrm{mg}$ of oxygen per liter per minute is consumed by the fish, the fish can produce $0.1 \mathrm{mg}$ of TAN ${ }^{(25)}$. In this experiment the TAN was maintained $(0.40-0.41 \mathrm{mg} /)$ among the treatments which was far better.

Initial mean weight of cultured species was $0.36 \mathrm{~g}$ and those species were released to each treatment. Maximum weight gain $\left(149129 \mathrm{~g}\right.$ ) can be obtained at 7000 fries $/ 7 \mathrm{~m}^{3}$ (1000 fries $\left./ \mathrm{m}^{3}\right)$ stocking density comparing to other 4000 (82516 g), 5000 ( $112141 \mathrm{~g}$ ) and 6000 fries $/ 7 \mathrm{~m}^{3}(130411 \mathrm{~g})$ stocking densities. Considering the number of survived individuals and total mean weight gain, T4 showed better gain than any other treatments and it was achieved without hampering growth performance and nutrient quality after 120 days of culture (Table 4). 
Table 3. Mean water quality parameters in 120 days in RAS.

\begin{tabular}{cccccc}
\hline Treatment & $\begin{array}{c}\text { Dissolved } \\
\text { oxygen } \\
(\mathrm{mg} \Lambda)\end{array}$ & $\begin{array}{c}\text { Nitrate- } \\
\text { nitrogen } \\
(\mathrm{mg} \Lambda)\end{array}$ & $\begin{array}{c}\text { Total ammonia- } \\
\text { nitrogen } \\
(\mathrm{mg} \Lambda)\end{array}$ & $\begin{array}{c}\text { Nitrite- } \\
\text { nitrogen } \\
(\mathrm{mg} \Lambda)\end{array}$ & $\mathrm{pH}$ \\
\hline 1 & $16.20 \pm 0.12^{\mathrm{a}}$ & $0.34 \pm 0.01^{\mathrm{a}}$ & $0.41 \pm 0.01^{\mathrm{a}}$ & $0.32 \pm 0.01^{\mathrm{a}}$ & $7.0 \pm 0.12^{\mathrm{a}}$ \\
2 & $15.33 \pm 0.19^{\mathrm{a}}$ & $0.36 \pm 0.01^{\mathrm{a}}$ & $0.40 \pm 0.02^{\mathrm{a}}$ & $0.33 \pm 0.01^{\mathrm{a}}$ & $7.0 \pm 0.07^{\mathrm{a}}$ \\
3 & $15.83 \pm 0.32^{\mathrm{a}}$ & $0.35 \pm 0.01^{\mathrm{a}}$ & $0.41 \pm 0.02^{\mathrm{a}}$ & $0.32 \pm 0.01^{\mathrm{a}}$ & $7.0 \pm 0.18^{\mathrm{a}}$ \\
4 & $15.90 \pm 0.06^{\mathrm{a}}$ & $0.37 \pm 0.01^{\mathrm{a}}$ & $0.41 \pm 0.01^{\mathrm{a}}$ & $0.34 \pm 0.01^{\mathrm{a}}$ & $7.1 \pm 0.13^{\mathrm{a}}$ \\
\hline
\end{tabular}

aNo significant differences were detected among the treatments $(p>0.05)$ denoting same alphabet.

Table 4. Weight (g) (Mean \pm SEM) of Mystus cavasiusin each sampling period cultured in RAS.

\begin{tabular}{clllll}
\hline Treatment & $\begin{array}{l}\text { Initial } \\
\text { weight }\end{array}$ & $\begin{array}{l}\text { Final weight } \\
(120 \text { days })\end{array}$ & $\begin{array}{l}\text { Weight } \\
\text { gain }\end{array}$ & $\begin{array}{l}\text { Survived } \\
\text { individual }\end{array}$ & $\begin{array}{l}\text { Total weight } \\
\text { gain }\end{array}$ \\
\hline T1 & $0.36 \pm 0.03^{\mathrm{a}}$ & $21.41 \pm 0.11^{\mathrm{a}}$ & $21.05 \pm 0.21^{\mathrm{a}}$ & $3920 \pm 0.07^{\mathrm{a}}$ & $82516 \pm 0.22^{\mathrm{a}}$ \\
T2 & $0.36 \pm 0.07^{\mathrm{a}}$ & $22.96 \pm 0.17^{\mathrm{a}}$ & $22.60 \pm 0.15^{\mathrm{a}}$ & $4962 \pm 0.03^{\mathrm{a}}$ & $112141 \pm 0.18^{\mathrm{a}}$ \\
T3 & $0.36 \pm 0.04^{\mathrm{a}}$ & $22.23 \pm 0.23^{\mathrm{a}}$ & $21.87 \pm 0.14^{\mathrm{a}}$ & $5963 \pm 0.05^{\mathrm{a}}$ & $130411 \pm 0.15^{\mathrm{a}}$ \\
T4 & $0.36 \pm 0.02^{\mathrm{a}}$ & $21.87 \pm 0.14^{\mathrm{a}}$ & $21.51 \pm 0.18^{\mathrm{a}}$ & $6933 \pm 0.02^{\mathrm{a}}$ & $149129 \pm 0.17^{\mathrm{a}}$ \\
\hline
\end{tabular}

aNo significant differences were detected $(\mathrm{p}>0.05)$ among treatments denoting same alphabet reared for 120 days

At the end of the culture the highest gain was 31\% in T4 and lowest was $18 \%$ in $\mathrm{T} 1$ of total gain with same operational cost and other facilities such as power supply, water tank, oxygenation, water supply, biological and mechanical filtration of water etc (Fig. 1). Therefore T4 showed the best result after 120 days which was economically viable for the fish farmers. It is clear from this study that high stocking density in RAS did not affect the growth performance and proximate composition of Mystus cavasius. In outdoor culture condition, high stocking density is a limiting factor for fish culture and it increases fish mortality, affects the growth performance, decreases nutrient quality ${ }^{(26)}$. Different stocking density of fish in those culture conditions show fluctuating result in growth performance and nutrient quality. But this study showed no significant difference ( $p>$ 0.05 ) in growth performance and proximate composition among all treatments. Moreover survival rate was above $99 \%$ in this study which is impossible in outdoor culture system. Because high stocking density may lead to poor water quality and a crowding effect which affect fish health badly ${ }^{(27)}$. Overall result indicates that Mystus cavasius can be cultured in RAS up to 7000 fries $/ 7 \mathrm{~m}^{3}\left(1000\right.$ fries $\left./ \mathrm{m}^{3}\right)$ stocking density without hampering gain. 
Focus point of this study revealed that stocking density did not create negative impacts on growth performance of Mystus cavasius but it might be a limiting factor in outdoor culture system. Moreover, highest stocking density 7000 fries $/ 7 \mathrm{~m}^{3}$ (1000 fries $/ \mathrm{m}^{3}$ )



Fig. 1. Total gain (\%) in different stocking densities with same RAS facilities.

provided the best gain compared to other lower densities in RAS. However, further investigation may be carried out to observe the effects of high stocking density on polyculture of Mystus cavasius with other species using RAS.

\section{Acknowledgement}

The authors wish to express their gratitude to Ministry of Science and Technology, People's Republic of Bangladesh for providing financial assistance to this research work. They are thankful to RAS fish farm authority located at Manikgonj for their co-operation during this study.

\section{References}

1. Jayaram KC 1977. Aid to identification of siluroid fishes of India, Burma, Sri Lanka, Pakistan and Bangladesh. 1. Bagridae. Records of the Zoological Survey of India, Miscellaneous Publication, Occasional Paper 8: 1-41.

2. Jhingran VG 1991. Fish and Fisheries of India (3rd ed.). Hindustan Publishing Corporation, Delhi, India, $727 \mathrm{pp}$.

3. IUCN, Bangladesh 1998. List of threatened animals of Bangladesh. Paper presented in the special workshop on Bangladesh Red Book of Threatened Animals, 22 February 1998, Dhaka, pp. 13.

4. Chakraborty BK and MJA Mirza 2007. Effect of stocking density on survival and growth of endangered bata, Labeobata (Hamilton-Buchanan) in nursery ponds. Aquaculture 265: $156-162$ 
5. Rahman MA, MA Mazid, MR Rahman, MN Khan, MA Hossain and MG Hussain 2005. Effect of stocking density on survival and growth of critically endangered mahseer, Tor putitora (Hamilton) in nursery ponds. Aquaculture 249: 275-284.

6. Helfrich LA and G Libey 1991. Fish farming in recirculating aquaculture systems (RAS). Virginia State Cooperative Service, pp. 1-18.

7. Twarowska JG, PW Westerman and TM Losordo 1997. Water treatment and waste characterization evaluation of an intensive recirculating fish production system. Aquacultural Engineering 16(3): 133-147.

8. Timmons MB, ST Summerfelt and BJ Vinci 1998. Review of circular tank technology and management. Aquacultural Engineering 18(1): 51-69.

9. Rahman M, M Zaher, KM Azimuddin, S Yeasmine, M Khan and A Arshad 2013. Stocking density effects on growth and production of the threatened silurid catfish, Mystu scavasius (Hamilton) fingerlings in nursery ponds. Aquaculture Research 44(7): 1132- 1139.

10. Kohinoor AH, M Begum and MG Hussain 2004. Culture potentials of gulsha (Mystus cavasius) in management under stocking densities. Bangladesh Journal of Fisheries Research 8(2): 95-100.

11. Castell JD and K Tiews 1980. Report of the IFAC,IUNS and ICES working group on the standardization of methodology in fish nutrition research. EIFAC technical paper 36. Hamburg, Federal Republic of Germany, 21-23 March, 1979, 24 pp.

12. AOAC (Association of Official Analytical Chemists) 1995. Official Method of Analysis, 12th edn. Washington. pp. 832.

13. Medawar PB 1945. Size, shape and age. Essays in Growth and Form, pp. 157-187.

14. Craig S, LA Helfrich, D Kuhn and MH Schwarz 2017. Understanding fish nutrition, feeds, and feeding, pp. 4-5.

15. Twarowska JG, PW Westerman and TM Losordo, 1997. Water treatment and waste characterization evaluation of an intensive recirculating fish production system. Aquacultural Engineering 16(3): 133-147.

16. Nikolsky GV 1963. The Ecology of Fishes. Academic press, London, pp. 352.

17. Dresosier NW 1977. Element of food technology. The Avi. Pub. Co. Inc. pp. 384.

18. Stansby ME 1963. Industrial fishery technology: A survey of methods for domestic harvesting, preservation, and processing of fish used for food and for industrial products. Reinhold Publishing, New York, pp. 393.

19. Bogard JR, SH Thilsted, GC Marks, MA Wahab, MA Hossain, J Jakobsen and J Stangoulis 2015. Nutrient composition of important fish species in Bangladesh and potential contribution to recommended nutrient intakes. Journal of Food Composition and Analysis 42: 120-133.

20. INFS 1983. Nutrition Survey of Rural Bangladesh, 1981-82, Institute of Nutrition and Food Science, University of Dhaka, Bangladesh, pp. 32-37.

21. Pillay TVR and MN Kutty 2005. Feed and nutrition. Aquaculture: Principles and Practices, 2nd ed., Blackwell Publishing, Oxford, pp.105-173.

22. Summerfelt ST, BJ Vinci and RH Piedrahita 2000. Oxygenation and carbondioxide control in water reuse systems. Aquacultural Engineering 22(1-2): 87-108. 
23. Summerfelt ST and MJ Sharrer 2004. Design implication of carbon dioxide production within biofilters contained in recirculating salmonid culture systems. Aquacultural Engineering, 32(1): 171-182.

24. Fivelstad S, H Haavik, G Løvik and AB Olsen 1998. Sublethal effects and safe levels of carbondioxide for Atlantic salmon post-smolt (Salmosalar L.). Aquaculture 160: 305-316.

25. Timmons MB, JM Ebeling, FW Wheaton, ST Summerfelt and BJ Vinci 2002. Recirculating Aquaculture Systems, 2nd Edition. Cayuga Aqua Ventures, Ithaca, NY 14850, USA. 800 pp. NRAC Publication No.1-2.

26. Irwin S, J O'halloran and RD Fitz Gerald 1999. Stocking density, growth and growth variation in juvenile turbot, Scophthalmus maximus (Rafinesque). Aquaculture 178(1-2): 77-88.

27. Santos GA, JW Schrama, REP Mamauag, JHWM Rombout, JAJ Verreth 2010. Chronic stress impairs performance, energy metabolism and welfare indicators in European seabass (Dicentrarcu labrax): The combined effects of fish crowding and water quality deterioration. Aquaculture 299(1-4): 73-80.

(Manuscript received on 21 May, 2019; revised on 15 March, 2020) 